BBA 35304

\title{
NUCLEAR PHOSPHOPROTEINS
}

\section{ISOLATION AND CHARACTERIZATION OF A PHOSPHOPROTEIN FRACTION FROM CALF THYMUS NUCLEI}

\section{LEWIS J. KLEINSMITH AND VINCENT G. ALLFREY}

Department of Zoology, The University of Michigan, Ann Arbor, Mich. (U.S.A.) and The Rockefeller University, New York, N.Y. (U.S.A.)

(leceived July znd, I 968 )

\section{SUMMARY}

A phosphoprotein fraction has been isolated from calf thymus nuclei which contains about I. $3 \%$ alkali-labile phosphorus by wt. The enzymatic reaction in which serine and threonine residues in the protein are phosphorylated by the terminal phosphate of ATP (and other nucleoside triphosphates) has been extensively studied in vitro. The purified protein fraction contains endogenous kinase activity, so that protein phosphorylation proceeds without the need for any added enzyme. Radioactive phosphate groups incorporated in this reaction are stable to incubation in a medium containing an excess of unlabeled ATP, indicating that the enzyme activity responsible for the rapid "turnover" of protein-phosphate groups seen in intact nuclei is not an inherent part of the phosphoprotein. The reaction between ATP and the nuclear phosphoprotein is only slightly reversible, making it appear unlikely that this phosphoprotein functions as a high-energy phosphate reservoir or as a high-energy intermediate in oxidative phosphorylation.

\section{INTRODUCTION}

The occurrence of phosphoprotein fractions in a variety of cell types has been known for many years ${ }^{1-4}$, but it was not until quite recently that it was discovered that a major portion of the phosphoprotein fraction is localized in cell nuclei ${ }^{5,6}$. The phosphoprotein fraction from rat liver nuclei has been extensively purified and studied by LANGAN ${ }^{5}$. He found that this protein fraction inhibits the ability of histones to inhibit RNA polymerase activity in vitro, leading to the suggestion that phosphoprotein-histone interactions might function in the regulation of RNA synthesis.

In an attempt to find out more about the possible physiological function of the nuclear phosphoproteins, we have previously investigated the metabolism of this protein fraction in intact lymphocyte nuclei ${ }^{6,7}$. We have found that phosphorylation 
of serine and threonine residues in nuclear protein can be observed in isolated calf thymus nuclei utilizing [ ${ }^{32} \mathrm{P}$ orthophosphate as a precursor. The reaction is energydependent, and occurs after the polypeptide chain has been completed. The phosphate groups, once incorporated into the protein, are not stable, but are subject to a very rapid turnover reaction. An interesting finding is that the rate of these reactions is stimulated very early in the course of gene activation induced in lymphocytes with phytohemagglutinin, supporting the hypothesis that these proteins are involved in gene activity.

As an extension of these studies, the present paper describes the isolation and partial characterization of the phosphoprotein fraction from calf thymus nuclei. It has been found that this protein fraction is similar in several aspects to the one isolated from rat liver nuclei by LANGAN. It contains about $x .3 \%$ phosphorus by wt., or the equivalent of 4-5 phosphorylated amino acids per roo residues. The protein fraction retains its own phosphoprotein kinase activity, so that it can be phosphorylated directly in vitro by the addition of ATP and $\mathrm{Mg}^{2+}$ without the need for any other added enzyme. It has been discovered that in addition to ATP, several other ribonucleosideand deoxyribonucleoside triphosphates are capable of phosphorylating the protein in vitro. Unlike the case of phosvitin ${ }^{8}$, the enzymatic reaction between ATP and the nuclear phosphoprotein appears to be almost irreversible. Furthermore, phosphate groups which have been incorporated into the nuclear phosphoprotein in vitro are stable to incubation, indicating the absence of the enzyme activity which is responsible for the rapid "turnover" of phosphate groups seen in the phosphoproteins of intact nuclei ${ }^{6}$.

\section{METHODS}

\section{Purification of phosphoprotein from calf thymus nuclei}

The procedure employed for purification of the calf thymus nuclear phosphoprotein was a slight modification of the method developed by LANGAN AND LIPMANN ${ }^{5}$ for the isolation of phosphoprotein from rat liver nuclei. The rationale of the procedure is as follows. Nuclei are first isolated and are then washed with dilute salt solutions to remove the soluble nuclear proteins and ribosomes. The phosphoprotein is solubilized along with the DNA and histones by homogenizing in I.o $\mathrm{M} \mathrm{NaCl}$. The DNA and histones are then precipitated from this extract by lowering the salt concentration to $0.4 \mathrm{M}$. Any basic protein remaining in the supernatant is removed by a bulk adsorption with a cation-exchange resin. The phosphoprotein is then removed from the solution by adsorption on a calcium phosphate gel. The gel is washed and then dissolved in $0.2 \mathrm{M}$ EDTA, bringing the phosphoprotein into solution. The salts and EDTA are finally removed by gel filtration on Bio-Gel P-Io. The details of the procedure are described in the following paragraphs.

All steps of the purification were carried out at $4^{\circ}$. Nuclei were first prepared from $200 \mathrm{~g}$ fresh calf thymus according to the procedure of ALLFREY et al.$^{9}$. The nuclear suspension was sedimented at $1000 \times \mathrm{g}$, and was then washed first with $1000 \mathrm{ml}$ of o.OI M Tris ( $\mathrm{pH} 7.4$ ), $3 \mathrm{mM} \mathrm{MgCl}_{2}$, and then with $500 \mathrm{ml}$ of $0 . \mathrm{I}_{4} \mathrm{M} \mathrm{NaCl}$. After each wash the nuclei were collected by centrifugation at Iooo $\times g$ for 7 minutes. The sediment was resuspended in $270 \mathrm{ml}$ of $0.14 \mathrm{M} \mathrm{NaCl}$ and was then added to $270 \mathrm{ml}$ of $2.0 \mathrm{M}$ $\mathrm{NaCl}, 0.03 \mathrm{M}$ Tris ( $\mathrm{pH}$ 7.4). The resulting gel was homogenized for $5 \mathrm{~min}$ at Iooo rev./ 
min in a Waring blendor, and was then centrifuged for $15 \mathrm{~min}$ at $33000 \times \mathrm{g}$. The supernatant was collected and slowly diluted with I.5 vol. of $0.02 \mathrm{M}$ Tris ( $\mathrm{pH} 7.4$ ); the nucleoprotein aggregate which formed was dispersed by blending for 2 min at Iooo rev./min in the Waring blendor. The resulting suspension was centrifuged for 75 min at $105000 \times g$.

To the supernatant was added Io g of Bio-Rex $70\left(\mathrm{Na}^{+}\right)$which had been equilibrated with $0.4 \mathrm{M} \mathrm{NaCl}, 0.02 \mathrm{M}$ Tris ( $\mathrm{pH} 7.4$ ). After stirring Io min, the suspension was centrifuged to min at $6000 \times g$ and the resin washed with $50 \mathrm{ml} 0.4 \mathrm{M} \mathrm{NaCl}, 0.02 \mathrm{M}$ Tris ( $\mathrm{pH} 7.4)$. The two supernatants were combined and $66 \mathrm{mg}$ of calcium phosphate gel added ${ }^{\mathbf{1 0}}$. After stirring $\mathrm{Io}$ min, the gel was collected by centrifuging $5 \mathrm{~min}$ at $6000 \times g$. It was washed by resuspending in Ioo $\mathrm{ml}$ of $\mathrm{I} .0 \mathrm{M}\left(\mathrm{NH}_{4}\right)_{2} \mathrm{SO}_{4}, 0.05 \mathrm{M}$ Tris $(\mathrm{pH} 7.4)$, and was again collected by centrifugation. The gel was then dissolved in $32 \mathrm{ml}$ of $0.2 \mathrm{M}$ EDTA $\left(\mathrm{pH}_{7.4}\right), 0.33 \mathrm{M}\left(\mathrm{NH}_{4}\right)_{2} \mathrm{SO}_{4}$ by gentle stirring for $45 \mathrm{~min}$. A small insoluble residue was removed by centrifuging to min at 33 ooo $\times g$, and the supernatant desalted by passing over a column of Bio-Gel P-IO $(2.5 \mathrm{~cm} \times 44 \mathrm{~cm})$ equilibrated with $0.05 \mathrm{M}$ Tris ( $\mathrm{pH}$ 7.4). The exclusion peak, containing I0-25 $\mathrm{mg}$ phosphoprotein, was collected and stored at $-90^{\circ}$. At this temperature the preparation is stable for at least a year.

\section{Analytical methods}

Alkali-labile phosphate, phosphoserine, and phosphothreonine were determined as described previously ${ }^{6}$. Amino acid analyses were performed on a Beckman automatic analyzer ${ }^{11}$.

Tryptophan was determined by a micro-scale modification of a method described by SPIES AND CHAMBERs ${ }^{12}$. Approximately $500 \mu \mathrm{g}$ of phosphoprotein was precipitated with Io vol. of acetone and resuspended in $0.5 \mathrm{ml}$ of a solution of dimethylaminobenzaldehyde $\left(3 \mathrm{mg} / \mathrm{ml}\right.$ in $\left.9.5 \mathrm{M} \mathrm{H}_{2} \mathrm{SO}_{4}\right)$. After standing in the dark for $\mathrm{I} 9 \mathrm{~h}$ with occasional stirring, $0.025 \mathrm{ml}$ of $0.009 \% \mathrm{NaNO}_{2}$ was added, and the resulting color read $30 \mathrm{~min}$ later at 6 Io $\mathrm{m} \mu$. A standard curve was run with tubes containing 2,4 , and $8 \mu$ g tryptophan in the same volume.

\section{Assay of enzymatic phosphorylation of nuclear phosphoprotein}

In the standard assay procedure, $0.5 \mathrm{ml}$ of final incubation mixture was made by combining the following components: $0.4 \mathrm{ml}$ of purified phosphoprotein in $0.05 \mathrm{M}$ Tris, $\mathrm{pH} 7.4$ (I00-I50 $\mu \mathrm{g} / \mathrm{ml}) ; 0.05 \mathrm{ml}$ of $0.05 \mathrm{M} \mathrm{MgCl}_{2}$; and $0.05 \mathrm{ml}$ of $\left[\gamma^{-32} \mathrm{P}\right] \mathrm{ATP}$ (I $\mathrm{m} \mu \mathrm{mole} / \mathrm{ml}, 300-3000 \mathrm{mC} / \mathrm{mmole}$ ). Tubes were incubated for Io min at $37^{\circ}$, and the reaction stopped with cold $25 \%$ trichloroacetic acid. To each tube $0.5 \mathrm{mg}$ phosvitin was added as carrier, and the precipitates were washed three times with cold $25 \%$ trichloroacetic acid and once with $20 \%$ ethanol in ether. Incorporation of ${ }^{32} \mathrm{P}$ into alkali-labile phosphate was determined as described previously ${ }^{6}$. About $90 \%$ of the counts in the alkali-labile phosphate fraction originate from phosphoserine, and the remaining $10 \%$ are from phosphothreonine.

${ }^{32} \mathrm{P}$-labeled nucleoside triphosphates were obtained from International Chemical and Nuclear Corporation. $\left[\beta_{-}{ }^{32} \mathrm{P}\right] \mathrm{ADP}$ was prepared from $\left[\beta, \gamma^{-32} \mathrm{P}\right\rfloor \mathrm{ATP}$ obtained from Schwartz Bioresearch. The $\beta, \gamma$-labeled ATP was incubated for $20 \mathrm{~min}$ with the phosphoprotein as described above in order to cleave the terminal phosphate linkage and form $\left[\beta{ }^{32} \mathrm{P}\right] \mathrm{ADP}$. The material was then placed on a column of Bio-GelTE-2 $(0.9 \mathrm{~cm} \times$ 


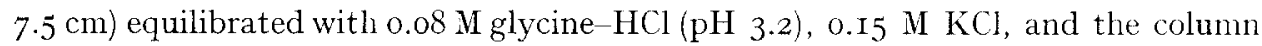
eluted with the same buffer. The $\left[\beta-{ }^{32} \mathrm{P}\right] \mathrm{ADP}$ passes through the column quickly and was collected, leaving the $\left[\beta, \gamma^{-32} \mathrm{P}\right]$ ATP behind.

\section{Preparation of ${ }^{32} P$-labeled phosphoprotein}

In order to study the reversibility of the phosphorylation reaction, phosphoprotein was labeled with ${ }^{32} \mathrm{P}$ by incubating it in the presence of $\left[\gamma_{-}{ }^{32} \mathrm{P}\right] \mathrm{ATP}$ as described above. After 20 min of incubation, the mixture was extensively dialyzed in the cold, first against 0.0 I M EDTA $(\mathrm{pH} \mathrm{7.4)}$ ), and then against $0.05 \mathrm{M}$ Tris $(\mathrm{pH} 7.4), 5 \mathrm{mM}$ $\mathrm{MgCl}_{2}$. After dialysis the phosphoprotein was diluted to a final concentration of I00 000 counts/min per ml, and was incubated with excess ADP as described by RABINOWITZ AND LIPMANN ${ }^{8}$.

\section{RESULTS}

\section{Composition of purified phosphoprotein fraction}

The alkali-labile phosphorus content of the phosphoprotein fraction purified from calf thymus nuclei was found to be $\mathrm{I} .28 \%$, compared to I.I $4 \%$ obtained by $\mathrm{LANGAN}^{5}$ for the rat liver phosphoprotein (Table I). In both cases, this phosphorus

\section{TABLE I}

PHOSPHORUS CONTENT OF NLCLEAR PROTEIN

Data for the composition of rat liver nuclear phosphoprotein were obtained from LANGAN (ref. 5 , personal communication).

\begin{tabular}{|c|c|c|}
\hline & Calf thymus & Ratliver \\
\hline $\begin{array}{l}\text { Total nuclear protein } \\
\text { Purified phosphoprotein } \\
\text { Purification } \\
\text { Yield }\end{array}$ & $\begin{array}{l}0.07 \% \mathrm{P} \\
\text { I.28\% } \\
\text { I9 } \times \\
\text { I } 2 \%\end{array}$ & $\begin{array}{l}0.14 \% P \\
1.14 \% P \\
8 \times \\
25 \%\end{array}$ \\
\hline \multicolumn{3}{|l|}{$\begin{array}{c}\text { Maximal estimate of: } \\
\text { phosphoprotein }\end{array}$} \\
\hline $\begin{array}{l}\text { total dry wt. nucleus } \\
\text { phosphoprotein }\end{array}$ & 0.04 & 0.09 \\
\hline DNA & 0.14 & 0.49 \\
\hline
\end{tabular}

occurs primarily as phosphoserine, with smaller amounts (about ro \%) of phosphothreonine. The amino acid compositions of the phosphoproteins from these two different sources are also quite similar (Table II).

As has been pointed out by LANGAN ${ }^{5}$, the amino acid composition of the phosphoprotein fraction bears some resemblance to that of certain histone subfractions (see Table II). One difference between these two protein classes is the occurrence of tryptophan in the phosphoprotein fraction and its absence from the histones, but the major distinction between the amino acid compositions of these two types of protein is in the ratio of basic to acidic residues, which is much lower in the phosphoproteins 
TABLE II

COMPARISON OF AMINO ACID COMPOSITION OF NUCLEAR PHOSPHOPROTEIN AND HISTONE FRACTIONS

Amino acid compositions are expressed in terms of moles per Ioo moles of amino acids recovered (except for tryptophan which is expressed in terms of percent by wt). Composition of rat liver nuclear phosphoprotein is from $\mathrm{LANGAN}^{5}$, and data for the $\mathrm{F}_{2} \mathrm{~b}$ histone are from Busch ${ }^{\mathbf{1 3}}$.

\begin{tabular}{|c|c|c|c|}
\hline & \multicolumn{2}{|c|}{ Nuclear phosphoprotein } & \multirow{2}{*}{$\begin{array}{c}\text { Histone } \\
\left(F_{2 b}\right)\end{array}$} \\
\hline & Calf thymus & Rat liver & \\
\hline Lysine & $9 \cdot 4$ & 8.0 & $\mathrm{I} 4 \cdot 5$ \\
\hline Histidine & I. 9 & 2.2 & 2.5 \\
\hline Arginine & 8.5 & 9.8 & $7 \cdot 5$ \\
\hline Aspartic acid & 10.5 & $9 \cdot 5$ & $5 \cdot 5$ \\
\hline Glutamic acid & I 4.9 & I 3.5 & 9.0 \\
\hline Threonine & 3.8 & $4 \cdot 3$ & 6.5 \\
\hline Serine & 10.3 & I0. 3 & 9.0 \\
\hline Proline & 6.2 & $7 \cdot 1$ & $4 \cdot 5$ \\
\hline Glycine & 6.8 & 7.6 & 7.0 \\
\hline Alanine & 6.2 & 6.4 & 10.5 \\
\hline Cysteine & 0.6 & 0.3 & - \\
\hline Valine & $4 \cdot 5$ & $5 \cdot \mathrm{I}$ & 6.8 \\
\hline Methionine & I.9 & I. 6 & 0.7 \\
\hline Isoleucine & 3.0 & 3.2 & 5.0 \\
\hline Leucine & 6.2 & 6.5 & 6.0 \\
\hline Tyrosine & 2.4 & $2 . \mathrm{I}$ & 3.1 \\
\hline Phenylalanine & 2.8 & 2.7 & 2.0 \\
\hline Tryptophan & $0.9 \%$ & & - \\
\hline Phosphorus (alkali-labile) & I. $28 \%$ & I.I $4 \%$ & $0.02 \%$ \\
\hline Basics/Acidics & $0.7^{8}$ & 0.87 & 1.69 \\
\hline
\end{tabular}

than in the histones. This difference is reflected in a large difference in isoelectric points. At $\mathrm{pH} 7.2$, the histones carry a heavy positive charge and migrate rapidly toward the cathode during electrophoresis, while the phosphoprotein fraction carries a net negative charge and moves toward the anode (Fig. I). Although the phosphoproteins appear to be moving as one band during electrophoresis on cellulose polyacetate, preliminary experiments employing discontinuous polyacrylamide gel electrophoresis have indicated the presence of at least five separate components in this fraction.

The ultraviolet spectra of phosphoprotein preparations indicate the presence of another form of heterogeneity (Fig. 2). Calculations based on the ratio of absorbance at $280 \mathrm{~m} \mu / 260 \mathrm{~m} \mu$ (ref. I4) indicate the occurrence of from $5^{-12} \%$ nucleic acid by wt. in various phosphoprotein preparations. Thus far it has not been possible to completely separate the nucleic acid from the phosphoprotein by physical means, indicating the possibility that some type of binding exists between the two species. This observation is of possible interest in relation to the proposed role of the phosphoproteins in modifying chromatin structure and DNA template activity.

\section{Enzymatic phosphorylation of nuclear phosphoprotein}

The purified phosphoprotein fraction can be phosphorylated in vitro by incubating it in the presence of $\left[\gamma^{-32} \mathrm{P}\right] \mathrm{ATP}$ and $\mathrm{Mg}^{2+}$ (Table III). This reaction is different from similar reactions involving phosphoproteins such as casein and phosvitin in that it does not require the addition of the enzyme phosphoprotein kinase. That the reaction 


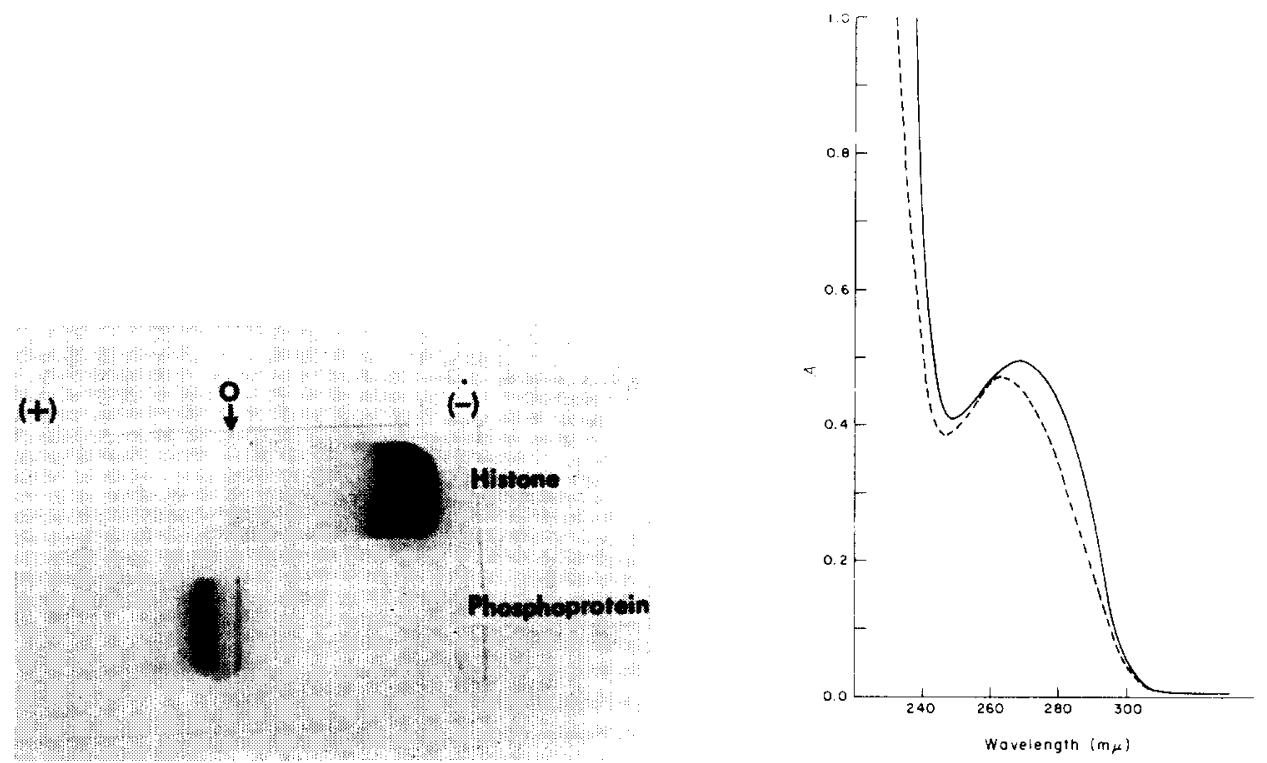

Fig. r. Electrophoretic patterns of phosphoprotein and histone preparations from calf thymus nuclei on cellulose polyacetate strips (o.o $\mathrm{M}$ Tris buffer, $\mathrm{pH} 7.2,40 \mathrm{~min}$ at $200 \mathrm{~V}$ ). The proteins were stained with Amido black toB.

Fig. 2. Ultraviolet spectra of two phosphoprotein preparations with different nucleic acid contents. Note that the spectra are considerably shifted away from $280 \mathrm{~m} \mu$ and toward $260 \mathrm{~m} \mu$, as would be expected if nucleic acids were present.

between ATP and the nuclear phosphoprotein is enzymatic is indicated by its thermal lability; it can be completely abolished by pre-heating the phosphoprotein for $3 \mathrm{~min}$ at $60^{\circ}$. Either the nuclear phosphoprotein fraction carries along some phosphoprotein kinase as a contaminant, or else the phosphoprotein has its own inherent kinase activity.

The standard incubation mixture used in the initial studies was made with a final concentration of $5 \mathrm{mM} \mathrm{MgCl} 2$ because this is the concentration employed in the past with phosphoprotein kinase systems ${ }^{5,8,15}$. When a $\mathrm{Mg}^{2+}$-concentration curve was

\section{TABLE III}

ENZYMATIC PHOSPHORYLATION OF NUCLEAR PHOSPHOPROTEIN

The purified phosphoprotein fraction was incubated for $10 \mathrm{~min}$ at $37^{\circ}$ in the presence of roo $\mu \mu \mathrm{moles}$ $\left[\gamma^{-32} \mathrm{P}\right]$ ATP and $5 \mathrm{mM} \mathrm{Mg}^{2+}$ as described in the text. Incorporation of ${ }^{32} \mathrm{P}$ into alkali-labile phosphate was then determined.

\begin{tabular}{|c|c|}
\hline & 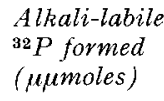 \\
\hline Complete system & 10.84 \\
\hline zero time & $0.0 \mathrm{I}$ \\
\hline minus $\mathrm{MgCl}_{2}$ & 0.03 \\
\hline
\end{tabular}

Biochim. Biophys. Acta, I75 (1969) I23-135 

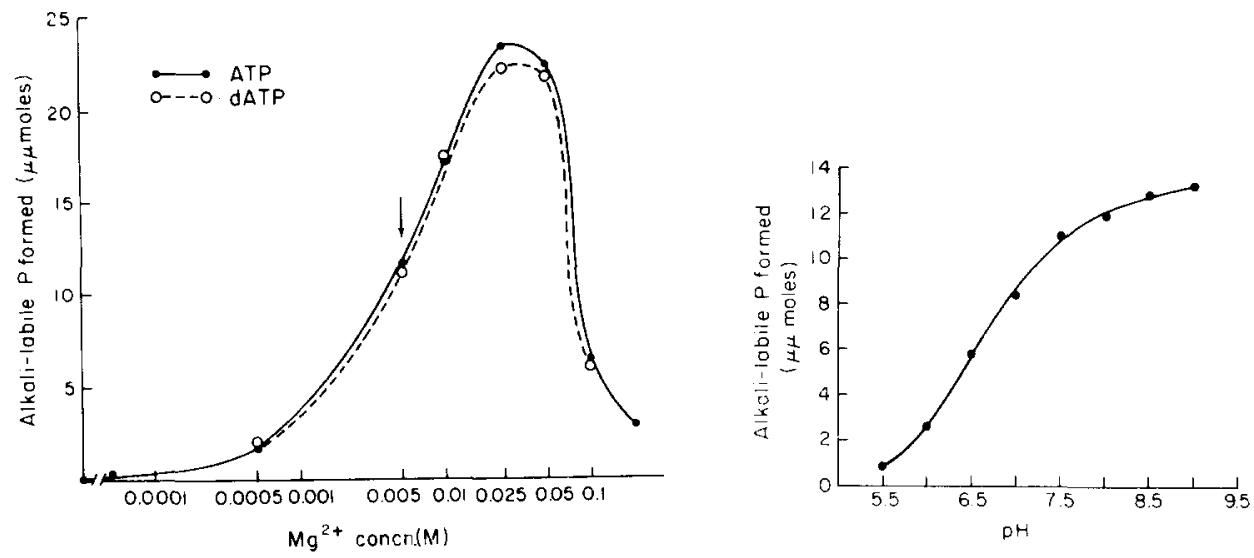

Fig. 3. Effect of varying $\mathrm{Mg}^{2+}$ concentration on the phosphorylation of nuclear phosphoprotein by $\left[\gamma^{-32} \mathrm{P}\right] \mathrm{ATP}$ and $\left[\gamma^{-32} \mathrm{P}\right] \mathrm{dATP}$. After $10 \mathrm{~min}$ of incubation with roo $\mu \mu$ moles of substrate, the incorporation of ${ }^{32} \mathrm{P}$ into alkali-labile phosphate was determined. The arrow indicates the concentration of $\mathrm{Mg}^{2+}(5 \mathrm{mM})$ usually employed in phosphoprotein kinase assay systems.

Fig. 4. Effect of $\mathrm{pH}$ on the phosphorylation of nuclear phosphoprotein by $\left[\boldsymbol{\gamma}^{32 \mathrm{P}}\right] \mathrm{ATP}$. After Io min of incubation, the incorporation of ${ }^{32} \mathrm{P}$ into alkali-labile phosphate was determined. Trismaleate buffer $\left(0.0_{4} \mathrm{M}\right)$ was used to extend the $\mathrm{pH}$ range.

run, however, it was found that the optimum for the nuclear phosphorylation reaction actually occurred closer to $25 \mathrm{mM} \mathrm{MgCl}_{2}$ (Fig. 3). The reaction exhibited a specific requirement for $\mathrm{Mg}^{2+}$; of I I other divalent cations tested, only $\mathrm{Fe}^{2+}, \mathrm{Mn}^{2+}$, and $\mathrm{Co}^{2+}$ showed significant activity, and these were only about half as active as $\mathrm{Mg}^{2+}$ (Table IV). Many of the divalent cations tested were highly inhibitory. In the presence of $5 \mathrm{mM}$ $\mathrm{Mg}^{2+}$, small amounts ( $\mathrm{ImM}$ ) of $\mathrm{Be}^{2+}, \mathrm{Zn}^{2+}$, and $\mathrm{Pd}^{2+}$ inhibited the phosphorylation reaction more than $95 \% ; \mathrm{Fe}^{2+}, \mathrm{Cu}^{2+}, \mathrm{Cd}^{2+}$, and $\mathrm{Ni}^{2+}$ were inhibitory to a lesser extent.

\section{TABLE IV}

EFFECTS OF DIVALENT CATIONS ON THE ENZYMATIC PHOSPHORYLATION OF NUCLEAR PHOSPHOPROTEIN

Nuclear phosphoprotein was incubated with $\left[\gamma_{-}^{32}\right]$ ATP for Io min with varying divalent cations present. Incorporation of ${ }^{32} \mathrm{P}$ into alkali-labile phosphate is expressed as percentage of value obtained when incubation was run with $\mathrm{Mg}^{2+}$.

\begin{tabular}{|c|c|c|}
\hline $\begin{array}{l}\text { Divalent } \\
\text { cation } \\
\text { tested }\end{array}$ & $\begin{array}{l}\text { No } M g^{2+} \\
5 m M X^{2+}\end{array}$ & $\begin{array}{l}5 m M M g^{2+} \\
I m_{\Lambda} M X^{2+}\end{array}$ \\
\hline $\mathrm{Mg}^{2}$ & I 00.0 & 100.0 \\
\hline $\mathrm{Fe}^{2+}$ & 60.3 & 7.5 \\
\hline $\mathrm{Mn}^{2+}$ & $5 \mathrm{I} .2$ & 100.5 \\
\hline $\mathrm{Co}^{2+}$ & $3^{6.8}$ & 77.0 \\
\hline $\mathrm{Ca}^{2}$ & 0.7 & I I 5.0 \\
\hline $13 a^{2+}$ & 1.5 & 103.7 \\
\hline $\mathrm{Cd}^{2+}$ & 3. I & 20.7 \\
\hline $\mathrm{Ni}^{2+}$ & I. 8 & $23 \cdot 3$ \\
\hline $\mathrm{Cu}^{2}+$ & 0.7 & 9.5 \\
\hline $\mathrm{Pd}^{2+}$ & 3.2 & 3. I \\
\hline $\mathrm{Zn}^{2+}$ & 2.4 & 2.2 \\
\hline $\mathrm{Be}^{2+}$ & 0.2 & I. 6 \\
\hline
\end{tabular}


TABLE V

ENZYMATIC PHOSPHORYLATION OF NUCLEAR PHOSPHOPROTEIN BY DIFFERENT SUBSTRATES

The purified phosphoprotein fraction was incubated for Io min at $37^{\circ}$ in the presence of roo $\mu \mu$ moles of substrate and $5 \mathrm{mM} \mathrm{Mg}{ }^{2+}$ as described in the text. Incorporation of ${ }^{32} \mathrm{P}$ into alkali-labile phosphate was determined as described in the text.

\begin{tabular}{|c|c|c|}
\hline \multirow[t]{2}{*}{ Substrate } & \multicolumn{2}{|c|}{ Alkali-labile ${ }^{32} P$ formed } \\
\hline & ( $\mu$ momoles) & $\begin{array}{l}(\% \text { of } A T P \\
\text { activity) }\end{array}$ \\
\hline$\left[\gamma_{-}{ }^{32} \mathrm{P}\right] \mathrm{ATP}$ & II, 26 & 100.0 \\
\hline$\left[\gamma-{ }^{32} \mathrm{P}\right] \mathrm{GTP}$ & $6.4^{6}$ & $57 \cdot 4$ \\
\hline$\left[\gamma-{ }^{32} \mathrm{P}\right] \mathrm{ITP}$ & 4.22 & 37.5 \\
\hline$[\gamma-32 \mathrm{P}] \mathrm{CTP}$ & 2.42 & $2 \mathrm{I} .5$ \\
\hline$[\gamma-32 \mathrm{P}] \mathrm{UTP}$ & 0.68 & 6.0 \\
\hline$[\gamma-32 \mathrm{P}] \mathrm{dATP}$ & I I.33 & I00.6 \\
\hline$[\beta-32 \mathrm{P}] \mathrm{ADP}$ & 0.25 & 2.2 \\
\hline${ }^{2} \mathrm{P}_{\mathrm{i}}$ & 0.06 & 0.5 \\
\hline${ }^{32} \mathrm{PP}$ & 0.002 & 0.02 \\
\hline
\end{tabular}

The phosphorylation of nuclear phosphoprotein in vitro does not exhibit a sharp $\mathrm{pH}$ optimum, but the reaction strongly favors the alkaline $\mathrm{pH}$ range (Fig. 4).

In an attempt to determine the substrate specificity of the phosphorylation reaction, various unlabeled nucleoside triphosphates were tested as competitive inhibitors of the reaction between $\left[\gamma^{-32} \mathrm{P}\right] \mathrm{ATP}$ and the phosphoprotein. It was found that in addition to nonradioactive ATP, the nucleotides GTP, CTP and UTP were also effective as competitive inhibitors of the reaction (Fig. 5). Although none of the latter were as effective as ATP, the results indicated the possibility that these nucleoside triphosphates might be active as phosphoryl group donors. When this possibility was
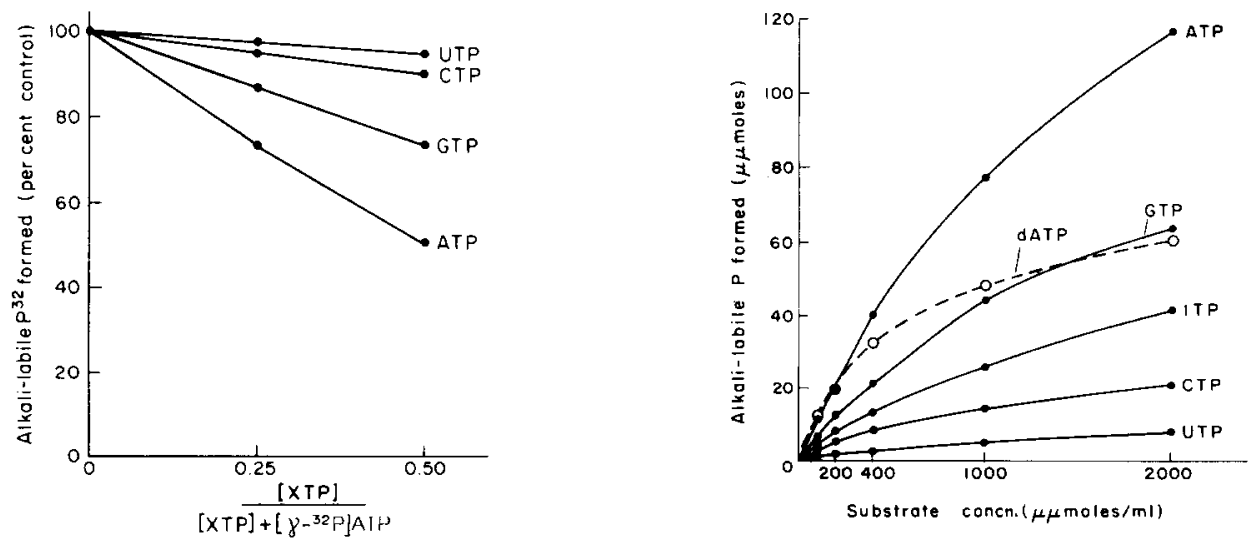

Fig. 5. Effects of different unlabeled nucleoside triphosphates on the phosphorylation of nuclear phosphoprotein by $\left[\gamma^{-32} \mathrm{P}\right] \mathrm{ATP}$. Incorporation of ${ }^{32} \mathrm{P}$ into alkali-labile phosphate is plotted as a function of the percent of unlabeled nucleotide in the $\left[\gamma_{-}{ }^{32}\right.$ P $]$ ATP-XTP mixture.

Fig. 6. Rate of phosphorylation of nuclear phosphoprotein as a function of substrate concentration. All substrates were labeled in the $\gamma$-position with ${ }^{32} \mathrm{P}$. Note that dATP is as active as ATP in phosphorylating the protein only at low concentrations of substrate. 
tested by substituting the different ${ }^{32} \mathrm{P}$-labeled nucleoside triphosphates for $\left[\gamma^{32} \mathrm{P}\right]$ ATP in the incubation mixture, it was found that $\left[\gamma_{-}{ }^{32} \mathrm{P}\right] \mathrm{GTP},\left[\gamma_{-}{ }^{32} \mathrm{P}\right] \mathrm{ITP},\left[\gamma^{-32} \mathrm{P}\right] \mathrm{CTP}$, $\left[\gamma^{-32} \mathrm{P}\right] \mathrm{UTP}$, and $\left[\gamma^{32} \mathrm{P}\right] \mathrm{dATP}$ were all capable, to varying degrees, of labeling the phosphoprotein (Table V). On the other hand, $\left[\beta-{ }^{32} \mathrm{P}\right] \mathrm{ADP},\left[{ }^{32} \mathrm{P}\right]$ pyrophosphate, and ${ }^{32} \mathrm{P}$ ]orthophosphate were inactive as phosphorylating agents.

Of all the nucleoside triphosphates tested as possible phosphate donors, only dATP appeared to be as active as ATP in phosphorylating the phosphoprotein (Table $V)$. However, when the reaction was studied at varying concentrations of substrate, it was discovered that dATP is as active as ATP only at low substrate concentrations; at higher concentrations, dATP is much less effective than ATP as a phosphorylating agent (Fig. 6). When the change in reaction velocity is plotted as a function of substrate concentration, it is seen that all the ribonucleoside triphosphates (ATP, GTP, ITP, CTP, UTP) follow the same curve, while the dATP exhibits a much lower rate of increase in reaction velocity with increasing substrate concentration (Fig. 7). The
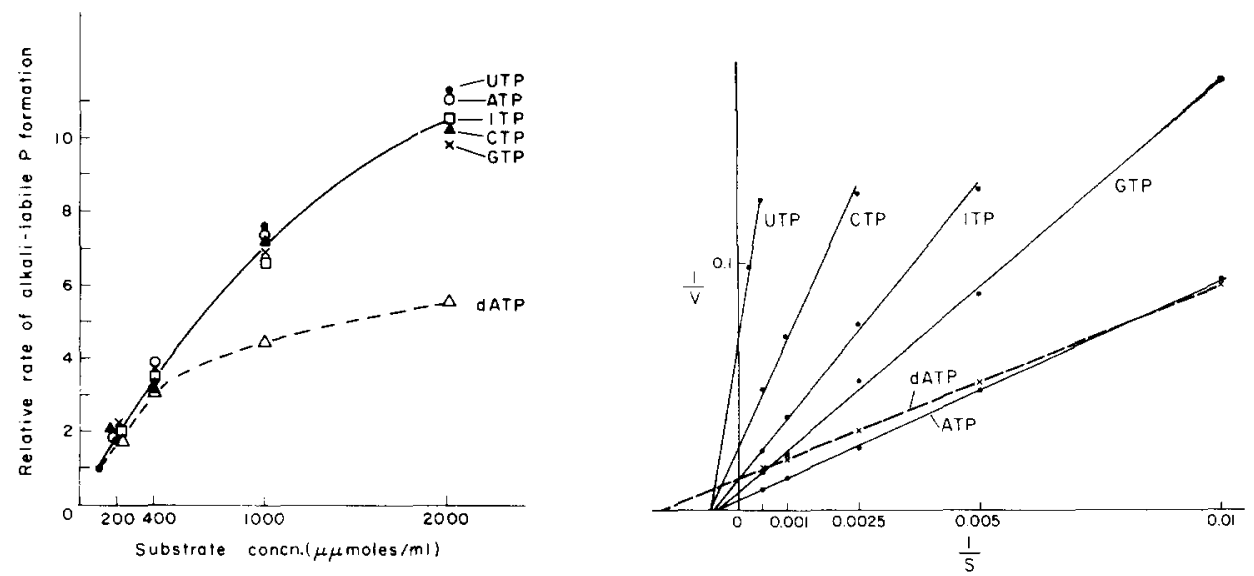

Fig. 7. Data from Fig. 6 are replotted by setting all the reaction rates at the lowest substrate concentration tested equal to $\mathbf{I}$. In this way, the relative increase in reaction rates with increasing substrate concentration can be compared. Note that all the ribonucleoside triphosphates exhibit a similar increase in reaction velocity with increasing substrate concentration, and that the rate of this increase is considerably greater than that seen with dATP.

Fig. 8. The data of Fig. 6 are replotted according to the method of LiNEwEAVER AND BURK ${ }^{\mathbf{1 6}}$. The intercept with the $x$ axis equals the negative reciprocal of the Michaelis constant $\left(K_{m}\right)$. Note that the ribonucleoside triphosphates share a similar $K_{m}$, which is considerably higher than that of $\mathrm{dATP}$ in the reaction.

meaning of this relationship becomes apparent when the data are replotted according to the method of LINEwEAVER AND BURK ${ }^{16}$, where it is discovered that the various ribonucleoside triphosphates share a common Michaelis constant $\left(K_{m}\right)$, which is considerably higher than the $K_{m}$ for dATP (Fig. 8).

\section{Reversibility of the phosphorylation reaction}

Since the phosphorylation of phosvitin by ATP is known to be a reversible reaction ${ }^{8}$, experiments were performed to determine whether the phosphorylation of 
TABILE VI

REVERSIBILITY OF REACTION BETWEEN ATP'ANIJ NLICLEAR PHOSPHOHROTLAN

${ }^{32} \mathrm{P}$-labeled phosphoprotein was prepared as described in the text, and was incubated at a finat concentration of $400 \mu \mathrm{g} / \mathrm{ml}(5.5400$ counts $/ \mathrm{ml})$ with $\mathrm{ADP}$ ( $100 \mathrm{~m} \mu \mathrm{mole} / \mathrm{ml})$ and $\mathrm{MgC}]_{2}(5 / \mu \mathrm{mole}$; $\mathrm{ml}$ ). After $2 \mathrm{~h}$ of incubation, formation of radioactive ATP was retermined by adsorption on charcoal as described by RABINOWITZ AND LIPMANN".

\begin{tabular}{ll}
\hline$p H$ & $\begin{array}{l}\text { ATP formed } \\
\text { (counts/min) }\end{array}$ \\
\hline 7.5 & 140 \\
7.0 & 202 \\
6.5 & 242 \\
0.0 & 162 \\
\hline
\end{tabular}

the nuclear phosphoprotein by ATP is also reversible. ${ }^{32} \mathrm{P}$-labeled phosphoprotein was incubated for $2 \mathrm{~h}$ with excess ADP, after which the reaction mixture was assayed to see if any radioactive ATP had been formed. The results, summarized in Table VI, indicate that less than $\mathrm{I} \%$ of the counts from the phosphoprotein are transferred to ADP during this time. This small amount of reversibility does not appear to be an artifact, since the reaction shows a $\mathrm{pH}$ optimum at $\mathrm{pH} 6.5$, the same point as the optimum for the reaction in the phosvitin-ATP system. However, the amount of reversibility is less than one-tenth that observed with phosvitin.

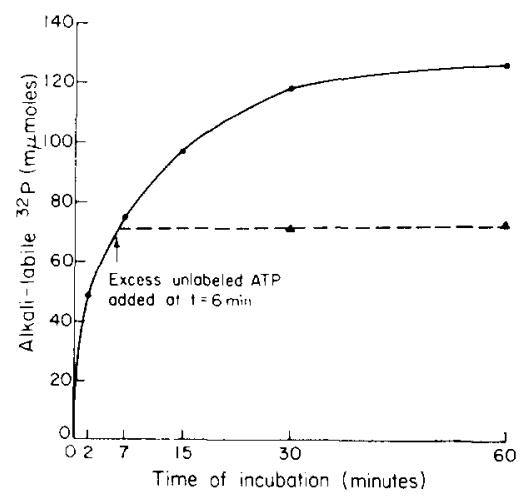

Fig. 9. Retention of ${ }^{32} \mathrm{P}$ by nuclear phosphoprotein during "cold chase" conditions. After $6 \mathrm{~min}$ of incubation with I00 $\mu \mu$ moles of $[\gamma$-32P]ATP, excess unlabeled ATP (I00 $\mu$ moles) was added to several of the tubes. The dashed line shows that the ${ }^{32} \mathrm{P}$ counts already incorporated into the protein in these tubes are stable to further incubation.

\section{Lack of phosphoprotein-phosphate "turnover" in vitro}

Since phosphoproteins labeled with ${ }^{32} \mathrm{P}$ in intact nuclei have been shown to rapidly "turn over" their phosphate groups in cold chase experiments ${ }^{6}$, the question arose as to whether a similar phenomenon takes place in the isolated phosphoprotein. Purified phosphoprotein was incubated for $6 \mathrm{~min}$ in the presence of $\mathrm{Mg}^{2+}$ and $\left[\gamma^{32} \mathrm{P}\right]$ ATP and was then "chased" by the sudden addition of a thousand-fold excess of unlabeled ATP. The results, summarized in Fig. 9, show that the phosphate groups, once incorporated into the protein, do not "turn over" under cold chase conditions but remain stably bound to the protein. 
DISCUSSION

The phosphoprotein fraction purified from calf thymus nuclei is similar in many of its chemical and physical properties to the preparation obtained from rat liver nuclei by LANGAN5. It should be emphasized that these protein fractions are still heterogeneous, so that the value of I.I-I.3\% phosphorus for these proteins represents a minimal estimate. If it is assumed for the sake of discussion that this value is approximately correct, then some interesting theoretical calculations can be made (see Table I). For instance, it is found that the phosphoproteins account for $4 \%$ of the total dry wt. of the thymus nucleus, and $9 \%$ of the total dry wt. of the liver nucleus. Even if the value of $1.2 \%$ phosphorus is low by a factor of Io, which seems exceedingly unlikely on the basis of the properties of the phosphoprotein fraction, then the phosphoproteins would still account for $0.4 \%$ and $0.9 \%$ of the total dry wt. of the thymus and liver nucleus respectively. These values are much higher than would be expected of an enzyme present in catalytic amounts, and point to the conclusion that the phosphoproteins are a major structural component of the cell nucleus.

Another interesting relationship which emerges from such theoretical calculations is the difference between liver and thymus nuclei in regard to their concentration of phosphoprotein per mg DNA. The maximal estimates for the phosphoprotein/ DNA ratio are 0.49 in liver and $0 . \mathrm{I}_{4}$ in thymus. Although these are only estimates based on the assumption that the phosphoprotein contains $1.2 \%$ phosphorus, the conclusion that the liver nucleus contains more than three times as much phosphoprotein per mg DNA as the thymus nucleus is independent of this assumption. This is noteworthy because it is another example of a correlation between phosphoprotein content and the capacity for RNA synthesis; liver nuclei, which are largely derived from the metabolically active parenchymal cells and are very active in RNA synthesis, contain much more phosphoprotein in association with their DNA than do calf thymocyte nuclei, which are derived from small lymphocytes which are relatively inactive in RNA synthesis.

The similarities in amino acid composition between some histone fractions and nuclear phosphoproteins, as well as the occurrence of phosphoserine in some histone preparations, suggest the possibility that these may be related proteins s,6,17. Although $^{5,6}$ phosphoserine has been obtained from highly purified histone fractions, the possibility exists that this might still represent contamination of the histone fraction with other proteins or adsorbed peptides. However, LANGAN AND SMITH ${ }^{18}$ have recently reported the isolation of a protein phosphokinase from rat liver which catalyzes the phosphorylation of histones by ATP, but is not active with other phosphoproteins. The existence of such an enzyme supports the conclusion that the phosphoserine found in histone fractions does not originate from contamination by other proteins.

An interesting finding in the current studies is that nucleoside triphosphates other than ATP are capable of donating their terminal phosphate groups to nuclear phosphoproteins. In order to interpret the functional significance of this finding, it will be necessary to determine whether these different precursors are phosphorylating the same or different sites in the phosphoprotein. The fact that dATP has a higher affinity (lower $K_{m}$ ) for the nuclear phosphoprotein-kinase system than any of the ribonucleoside triphosphates is noteworthy, and may have some bearing on the proposed role of phosphoproteins in modifying chromatin structure. The deoxy- 
ribonucleoside triphosphates, such as dATP, are normal constituents of the cell nucleus whose concentrations would be expected to change during the cell cycle, and could conceivably be affecting the structural state of the chromatin through their reactivity with the phosphoprotein system.

The failure to find a large degree of reversibility in the reaction between ATP and the nuclear phosphoprotein indicates that the phosphoryl bonds in these proteins are not of high phosphoryl group transfer potential like those in phosvitin. This is further evidence against the possibility that nuclear phosphoprotein functions as either a "high-energy" phosphate reservoir or as a "high-energy" intermediate in oxidative phosphorylation.

Since the purified phosphoprotein is capable of being phosphorylated in vitro without the addition of any exogenous kinase, it can be concluded that this protein fraction contains its own kinase activity. It has not yet been possible to determine whether this kinase activity is an inherent part of the phosphoprotein, or whether it merely represents contamination of the phosphoprotein fraction with some phosphoprotein kinase. It has been possible to determine, however, that the enzyme activity responsible for the "turnover" of phosphate groups from the protein is not an inherent part of the phosphoprotein, since the rapid loss of ${ }^{32} \mathrm{P}$ from nuclear proteins seen in intact nuclei does not occur in the isolated system.

One of the major categories of phosphoprotein function which has not yet been ruled out in regard to the nuclear phosphoproteins is involvement in the enzymatic transfer of phosphate groups. From the current studies it is known that the phosphoprotein-phosphate group originates in the terminal phosphate of various nucleoside and deoxynucleoside triphosphates. It is also known that these phosphoproteinphosphate groups are rapidly removed from the protein in intact nuclei, but their metabolic fate is unknown. In order to determine whether we are dealing with a phosphoryl group transfer reaction, we must know what happens to these phosphoryl groups which are being continually "turned over". Experiments designed to answer this question are described in the following paper.

\section{ACKNOWLEDGEMENT}

This work was supported in part by Grant GM-049I9 from the United States Public Health Service.

\section{REFERENCES}

I J. N. Davidson, S. C. Frazer and W. C. Hutchinson, Biochem. J., 49 (I95I) 3 I I.

2 R. N. Johnson and S. Albert, J. Biol. Chem., 200 (I953) 335.

3 H. H. Williams-Ashman and E. P. Kennedy, Cancer Res., I 2 (I952) 415.

4 E. P. Kennedy and S. W. Smith, J. Biol. Chem., 207 (1954) I 53.

5 T. A. Langan, in V. V. Koningsberger And L. Bosch, Regulation of Nucleic Acid and Protein Biosynthesis, Elsevier, Amsterdam, I967, p. 233.

6 L. J. Kleinsmith, V. G. Allfrey and A. E. Mirsky, Proc. Natl. Acad. Sci. U.S., 55 (1966) I 182 .

7 L. J. Kleinsmith, V. G. Allfrey and A. E. Mirsky, Science, I 54 (I966) 780.

8 M. Rabinowitz and F. Lipmann, J. Biol. Chem., 235 (Ig60) 1043.

9 V. G. Allfrey, A. E. Mirsky and S. Osawa, J. Gen. Physiol., 40 (I957) 45 I.

ro D. Keilin and E. F. Hartree, Proc. Roy. Soc. (London), Ser. B, I 24 (I938) 397.

i I D. H. Spackman, W. J. Stein and S. Moore, Anal. Chem., 30 (1958) i 190.

12 J. R. Spies AND D. C. Chambers, Anal. Chem., 2 I (I949) I 249.

Biochim. Biophys. Acta, I75 (1969) I 23-1 35 
I 3 H. Busch, Histones and Other Nuclear Proteins, Academic Press, N.Y., I965.

I 4 E. Layne, in S. P. Colowick and N. O. Kaplan, Methods in Enzymology, Vol. 3, Academic Press, N.Y., I 957 , p. 447.

is G. Burnett and E. P. Kennedy, $J$, Biol. Chem., 2 I I (1954) 969.

16 H. Lineweaver and D. Burk, $J$. Am. Chem. Soc., 56 (I934) 658 .

I 7 M. G. Ord and L. A. Stocken, Biochem. J., 98 (I966) 888.

i 8 T. A. Langan and L. K. Smith, Federation Proc., 26 (I967) 603.

Biochim. Biophys. Acta, I75 (1969) I23-135 